synthesizing enzyme with a protein in some circum. stances (depending upon structural interrelationships) by which the protein and the enzyme were reconstituted together. The next step could be the development of a differentiated envelope for the protein mass associated with its own synthesizing enzyme. Many synergistic components may have followed, each of which facilitated the synthesis of the complex, and each of which halted all syntheses when the particular components necessary for its construction were in short supply.

The demonstration of the essential nature of the gene depends upon the fact that deletion of a gene produces a lethal result. It is clear from the previous discussion that this fact does not prove that the gene is a primary component of the cell. Actually, one would expect co-ordinating and regulating functions to be superimposed late in the evolution of the cell. Many synthetic steps might involve minute amounts of regulatory materials which were required to act upon a specific substrate for a specific purpose. The critical value of the gene may depend on such a device. The control of adaptive enzymes by genes suggests that such trivial but occasionally valuable activities are controlled by genes. During the early phases of the development of gene theory it was proposed that genes differentiated specific or varietal characters while cytoplasm differentiated characteristics distinguishing genera or phyla. One ordinarily thinks of controlling, supervising and coordinating functions as relatively recent rather than primary activities of organizations whether they be cities or countries or cultures; genes may be recent agents in the origin of life carrying on functions similar to those of the electrical devices in a city such as Chicago.

There is a specific characteristic which is not consistent with the view that genes are composed of deoxyribonucleic acid. Evidence ${ }^{8}$ concerning the gene controlling galactose-fermentation in Saccharo- myces has been interpreted to indicate that genes may be plastic, since the substrate for a gene controlling the production of an adaptive enzyme is itself a mutagen controlling the mutation of the gene from a non-functional to a functional state. Similar instances have been encountered in studying the genes controlling carbohydrate fermentation in Saccharomyces. Rather than a rigid structure such as deoxyribonucleic acid, the genes themselves may be plastic materials attached to deoxyribonucleic acid. Lindegren $^{9}$ suggested that the rigidity of the chromosome made it an ideal site for assembly-line synthesis of gene-products, and the brilliant researches of Demerec (personal communication) have revealed that such assembly-line syntheses actually do occur. There is evidence ${ }^{10}$ that gene products may not always be synthesized at the locus of the gene, and this suggestion leads one to suppose that the fibrous nature of the chromosome is exploited as a means of communication and co-ordination, and that the basic functions of deoxyribonucleic acid are to hold the plastic material of the gene in place and to transmit information from it to a functioning cell centre.

This work was supported by grants from the Illinois Division of the American Cancer Society and the U.S. Atomic Energy Commission, $A T(11-$ 1) 176 .

\footnotetext{
1 Watson, J. D., and Crick, F. H. C., Nature, 171, 964 (1953).

2 Hotchkiss, R. D., Symposium on Genetic Recombination, The Biology Division, Oak Ridge National Laboratory, Oak Ridge, Tenn. (1954).

${ }^{3}$ Muller, H. J., Science, 121, 1 (1955).

"Michaelis, P., “Adv. in Genetics", 2, 1 (1948).

5 Renner, O., Ber. d. Math-Phys. Kl. d. Sachs. Akad. d. Wiss., 86, 241 (1934).

- Harder, R. A., Z. Bot., 19, 337 (1927).

7 Lindegren, C. C., Symp. Soc. Exp. Biol., 6, 277 (1952).

- Lindegren, C. C., and Pittman, D., J. Gen. Microbiol., 9, 494 (1953).

"Lindegren, C. C., "The Yeast Cell : Its Genetics and Cytology" (Educational P'ublishers, Inc., St. Louis, Mo., 1949).

${ }^{10}$ Lindegren, C. C., Experientia, 9, 75 (1953).
}

\title{
OBITUARIES
}

\section{Sir Arthur Tansley, F.R.S.}

Str Arthur Tanstey, who died on November 25, must be ranked as one of the makers of British botany. During his long and active life he exerted a profound influence on the development of the science and on the attitude of botanists towards the study of the plant world.

Tansley was born in 1871, educated at Highgate School, University College London, and Trinity College, Cambridge. At University College he came under that inspiring personality $\mathrm{F}$. W. Oliver, and at Cambridge he was influenced by Francis Darwin, Seward, and F. F. Blackman, who for many years was one of his closest friends. After taking a first class in Part II of the Natural Sciences Tripos at Cambridge, he returned to London as Quain Student at University College, later becoming domonstrator and assistant professor there. At this period he was much interested in evolutionary problems, then so much in the minds of botanists; he worked on the anatomy of ferns and on seedling structure. In 1902 he embarked on the bold venture of founding a new botanical periodical, The New Phytologist, which was to be "a medium of easy communication between British Botanists". He realized that this was a hazardous exporiment, and at first he acted both as editor and publisher. The experiment proved completely successful, and in the thirty years during which he was editor the journal became one of the principal botanical publications in the world. It frequently contained important contributions by the editor, such as his "Lectures on the Evolution of the Filicinean Vascular System". It was important, too, in promoting an integration of the various branches of botany hitherto regarded as distinet.

In 1903 he married Edith Chick, his successor in the Quain studentship, and three years later he returned to Cambridge as University lecturer. $\mathrm{H}_{\Theta}$ settled in a beautiful home at Grantchester which became a centre for botanists young and old. His lectures presented fresh points of view, especially those on ecology, at that time a new subject in Britain. Tansley had begun this study in London with Oliver, and he became an active member of the Committee for the Study of British Vegetation. The work of 
this Committee, and the articles in The New Phytologist on "Vegetation at Home and Abroad", did much to spread an interest in plant ecology which brought together taxonomists, physiologists and anatomists. In 1911 he organized the first International Phytogeographical Excursion to the British Isles. For this he produced a noteworthy book, "Types of British Vegetation". Two years later he took a leading part in the formation of the British Ecological Society, of which he was the first president; during 1916-37 he edited the Society's Journal of Ecology.

During the First World War Tansley undertook work in the Ministry of Munitions, and afterwards he spent a period in Vienna with Prof. Freud. This resulted in his well-known book "The New Psychology", which spread a knowledge of Freud's theories widely in Britain. Afterwards his mind became much occupied with the teaching of botany in schools, and in 1922 he produced an admirable text-book, "Elements of Plant Biology", which had a far-reaching influonce. In 1923 he was president of Section K (Botany) of the British Association, and delivered a very stimulating address on the position of botany at that time, in which he called for a new outlook in the study of plants. In the same year he resigned his university post at Cambridge and for a few years occupied himself with research and writing. His important work with T. F. Chipp on "Aims and Methods in the Study of Vegetation", and his "Practical Plant Ecology" date from this period.

A new phase in his career came in 1927 with his election as Sherardian professor of botany and fellow of Magdalen College at Oxford. Here he did much to stimulate and reorganize the study of botany. He collected around him a group of able young men and restored the old prestige of the department. $\mathrm{He}$ did much to prepare the way for the provision of a new building, though this was not constructed until after the Second World War.

On his retirement from Oxford in 1937 he devoted himself mainly to the completion of his monumental work, "The British Islands and their Vegetation", in which his own wide knowledge and the labours of British ecologists over some thirty years were epitomized. This fine volume, written in the lucid style which characterized all his works, will long remain as a memorial to his influence and enthusiasm; and it gained for him the Gold Medal of the Linnean Society of London. But his energies were still by no means exhausted, and in 1943 he became chairman of a committee to consider nature conservation and nature reserves in post-war Britain. His book, "Our Heritage of Wild Nature", and his addresses on various occasions did much to arouse a conscious. ness of the value to the nation of the preservation of areas inhabited by interesting plants and animals. He took an active part in the plan for helping teachers and students of all kinds to study plants and animals in their natural habitats, becoming president of the Council for the Promotion of Field Studies; he also provided students with "An Introduction to Plant Ecology", and was joint author of "Plant Ecology and the School". His appointment as first chairman of the Nature Conservancy in 1949 was a fitting climax to his efforts for so many years.

Tansley's work was recognized by his election to the Royal Society in 1915, to an honorary fellowship at Trinity College, Cambridge, in 1944, and by the conferment of a knighthood in 1950 .

He will be widely mourned as a leader and a friend.

$$
\text { H. Hamshaw Thomas }
$$

\section{Sir Richard Paget, Bart.}

Sir Richard Arithur Surtees Paget died on October 23 at the age of eighty-six. He was educated at Eton and Magdalen College, Oxford. After qualifying as a barrister and becoming a member of the Inner Temple, he gave valuable services on a number of industrial panels and commissions, where his genial personal qualities fitted him well as a negotiator. The bulk of his life, however, was spent in the cause of science. He loved science and brought the scientific attitude of mind to bear upon problems in many diverse fields-thus he achieved important work and gained distinction in physics, anthropology, architecture, town planning, acoustics, linguistics, speech and several artistic crafts. He was, moreover, of an inventive turn of mind, delighting in novel and unorthodox ways of viewing things, so that it is not surprising that he anticipated by half a century some present-day developments such as the streamline motor-car.

When in 1915 Britain was faced with calamity, he was one of the first to realize the urgency of well. directed scientific research on a national scale; he acted as assistant secretary of Section II of the Admiralty Board of Invention and Research during 1915-18. Not a few of the practical investigations undertaken by the Board during the First World War were the direct result of his foresight, to which tribute was paid on more than one occasion by the late Sir William Bragg, who was in charge of experimental work for the Navy.

Mention must be made of Sir Richard's keen interest in the arts. He was an accomplished musician, being particularly adept at keyboard improvization and composition. Folk music had a great fascination for him and provided an interest which he was ultimately able to link with his later studies on speech and language. Coupled with his inventiveness was a rare manual dexterity leading to skill in scientific experimentation and many forms of practical art ; for example, he excelled in the manufacture of pottery. As recently as June 1954, prior to a Friday Evening Discourse at the Royal Institution, he created intense interest by demonstrating his early models of the action of the vocal apparatus by which he could reproduce consonants and vowels, thereby simulating human speech. Though these models were connected with work done more than forty years ago, they struck the observer most forcibly at once by the elegance of their simplicity and their appropriateness for the purpose in hand. It is good to know that Sir Lawrence Bragg has now received the models for the Royal Institution Museum and will use them in his lectures from time to time.

Perhaps the most outstanding work of Sir Richard Paget was that upon speech and language. His extreme humanitarianism led him to exert himself to the full in the cause of the deaf and dumb. He put much effort into the development of a sign language for their use.

Several glowing appreciations of Sir Richard's scientific work have already appeared in the Press, both at home and overseas. All of them stress his amazing versatility, his originality of outlook, his zest for life and, above all, his great personal charm and humanity. Perhaps, in concluding, I may be permitted to introduce a personal note. When in 1938 I was faced with the task of opening the large new South-West Essex Technical College and School of Art, the extremely diverse problems involved in 